\title{
Radiographic closure time of appendicular growth plates in the Icelandic horse

\author{
Eric Strand ${ }^{* 1}$, Linn Camilla Braathen ${ }^{1}$, Mia C Hellsten ${ }^{1}$, Lisel Huse-Olsen ${ }^{1}$ \\ and Sigridur Bjornsdottir ${ }^{2}$
}

\author{
Address: ${ }^{1}$ Equine Teaching Hospital, Norwegian School of Veterinary Science, P.O.Box 8146 Dep. N-0033 Oslo, Norway and ${ }^{2}$ Agricultural \\ Authority of Iceland, Austurvegur 64, 800 Selfoss, Iceland \\ Email: Eric Strand* - eric.strand@veths.no; Linn Camilla Braathen - linca.braathen@hotmail.com; Mia C Hellsten - miahellsten@simnet.is; \\ Lisel Huse-Olsen - post@mjosa-hestklinikk.com; Sigridur Bjornsdottir - systa@ holar.is \\ * Corresponding author
}

Published: 17 July 2007

Acta Veterinaria Scandinavica 2007, 49:19 doi:10.1186/1751-0147-49-19

This article is available from: http://www.actavetscand.com/content/49/1/19

(c) 2007 Strand et al; licensee BioMed Central Ltd.

This is an Open Access article distributed under the terms of the Creative Commons Attribution License (http://creativecommons.org/licenses/by/2.0), which permits unrestricted use, distribution, and reproduction in any medium, provided the original work is properly cited.
Received: II October 2006

Accepted: 17 July 2007

\begin{abstract}
Background: The Icelandic horse is a pristine breed of horse which has a pure gene pool established more than a thousand years ago, and is approximately the same size as living and extinct wild breeds of horses. This study was performed to compare the length of the skeletal growth period of the "primitive" Icelandic horse relative to that reported for large horse breeds developed over the recent centuries. This information would provide practical guidance to owners and veterinarians as to when the skeleton is mature enough to commence training, and would be potentially interesting to those scientists investigating the pathogenesis of osteochondrosis. Interestingly, osteochondrosis has not been documented in the Icelandic horse.
\end{abstract}

Methods: The radiographic closure time of the appendicular growth plates was studied in 64 young Icelandic horses. The results were compared with previously published closure times reported for other, larger horse breeds. The radiographs were also examined for any signs of developmental orthopaedic diseases. In order to describe further the growth pattern of the Icelandic horse, the total serum alkaline phosphatase (ALP) activity was determined and the height at the withers was measured.

Results: Most of the examined growth plates were fully closed at the age of approximately three years. The horses reached adult height at this age; however ALP activity was still mildly increased over baseline values. The growth plates in the digits were the first to close at 8.1 to 8.5 months of age, and those in the regions of the distal radius ( 27.4 to 32.0 months), tuber olecrani ( 31.5 to 32.2 months), and the stifle (27.0 to 40.1 months) were the last to close. No horse was found to have osteochondrosis type lesions in the neighbouring joints of the evaluated growth plates.

Conclusion: The Icelandic horse appears to have similar radiographic closure times for most of the growth plates of its limbs as reported for large new breeds of horses developed during the past few centuries. It thus appears that different breeding goals and the intensity of breeding have not altered the length of the growth period in horses. Instead, it can be assumed that the pristine and relatively small Icelandic horse has a slower rate of growth. The appendicular skeleton of Icelandic horses has completed its bone growth in length at approximately 3 years of age, and therefore may be able to enter training at this time. 


\section{Background}

The growth plates at the distal radius and the tuber calcaneus have been used as indicators of skeletal maturity in Thoroughbred and Standardbred racing horses [1-3]. These breeds typically enter light training at 1.5 years of age, and formal race training at 2 years of age. It is widely thought among horsemen and veterinarians that Icelandic horses have open growth plates and grow in height until they are 4 to 5 years of age. As a result of this Icelandic horses do not receive demanding ridden training until they have reached that age. It is also thought that the slow growth rate over an extended period of time protects this breed from developing osteochondrosis, and other developmental orthopaedic disorders. To our knowledge, no study has been made regarding the closure time of the growth plates in the Icelandic horse, nor has anyone documented the existence of osteochondrosis in this breed.

The Icelandic horse has developed as an isolated breed since the settlement of the country in the 8th and 9th century. It originates from the medieval horse population of Norway and probably other countries in Scandinavia and the British Isles [4]. There is no evidence of introduction of new blood to the horse population since the end of the colonization period late in the 10th century [5]. The history of intense artificial selection of Icelandic horses is relatively short. Organized horse breeding based on different traits of conformation and performance under saddle has only been practised for one century [6-8]. For the last two decades, the breeding values have been obtained by a multiple-trait animal model (Best Linear Unbiased Prediction, BLUP) [9], accelerating the genetic improvement of the breed. The Icelandic horse is characterized by its ability to perform 4 or 5 gaits, and by its good health, and durability [10]. It is used for pleasure riding, long distance trekking and special gait competitions and has a wide distribution in Europe and North America [11].

The Icelandic horse is relatively small. Growth and development of the Icelandic horse was studied in the period 1970 - 1980 where the average height at the withers, measured by rod, was found to be $133 \mathrm{~cm}$ for five-year-old horses [12]. Measurements of horses presented for breeding evaluation in 2001 indicate an increase in the height of the breed in the last decades, as the average height of the mares was found to be $136.9 \mathrm{~cm}(128.0-146.0, \mathrm{SD}$ $2.8)$ and for stallions $138.6 \mathrm{~cm}$ (130.0 - 151.0, SD: 3.0$)$ [13].

The growth plate consists of a plate of hyaline cartilage, the physeal cartilage, and is seen on radiographs as a radiolucent line surrounded by diffuse relatively increased bone opacity. Endochondral ossification of the growth plates accounts for most of the linear growth of the long bones of the horse [14-16]. Cessation of this growth coin- cides with radiographic closure of the growth plate $[15,16]$. Radiographic closure has occurred when there is no radiolucent line visible in the physeal area. The closure time of selected growth plates of the limbs has been determined for some horse breeds [1-3,14,16-20].

Another method of evaluating the maturity of the skeleton is the measurement of biochemical parameters that are associated with growth and remodeling of bone tissue. Alkaline phosphatase (ALP) concentration in serum can be used to indicate the level of metabolic activity in the bone tissue of horses [21-23]. It reflects the active bone formation which accompanies skeletal modeling in the growing animal, and it decreases with age as the growth rate of the skeleton slows down [22-24].

The aims of this study were to determine the approximate radiographic closure time of the growth plates of the foreand hind limbs of the pristine Icelandic horse, and to compare these closure times with those previously published for more recently developed large breeds of horses. The radiographs were also examined in order to document evidence of developmental orthopaedic disease such as osteochondrosis and osteochondral bone cysts in the neighbouring joints. In order to further describe the growth pattern of the Icelandic horse, the total serum alkaline phosphatase (ALP) activity was determined, and the height at the withers was measured. This information would provide practical guidance to owners and veterinarians as to when the skeleton is mature enough to commence formal ridden training, and would be potentially interesting to those scientists investigating the pathogenesis of osteochondrosis.

\section{Methods \\ Horses}

The material consisted of 64 Icelandic horses, including 38 mares, 15 stallions and 11 geldings. Thirty-eight of the horses were examined in Iceland in late September 2004 and 26 in Norway in January and April 2005. The age of the horses ranged from 47 days to 52 months at the time of examination. All the horses were born during the spring and summer months, the majority in May and June of each year. Each horse was examined one time. All the horses were found to be in good nutritional condition. Further information about the management was collected from the owners: In Iceland, most of the young horses that were not in training were kept out-of-doors on large pastures all year round. The foals were weaned at approximately $6-9$ months of age, and were either stabled for the winter months or kept at pasture with access to open shelters. The feeding consisted of grazing from June to October/December, and haylage/silage ad lib out-ofdoors during the winter. Mineral supplements were usually provided by salt licks. In this material, the three-and- 
a-half-year-old horses (42 - 46 months) were being saddle broken, and the four and-a-half-year-olds (48 - 52 months) were in light training at the time of examination. The management regimes in Norway were similar, except for supplementary feeding of grain to all horses from weaning, and that most of the horses in Norway were stabled during the winter months. The horses were privately owned, and intended for pleasure riding and gait competitions. They had no history of illness or injury.

\section{Radiographic examination}

The horses were sedated with a combination of detomidine (Domosedan ${ }^{\circledast}$, Orion Corporation, Turku, Finland) $10-40 \mu \mathrm{g} / \mathrm{kg}$ bwt and butorfanol (Torbugesic ${ }^{\oplus}$, Fort Dodge Animal Health, Overland Park, Kansas, USA) 20$30 \mu \mathrm{g} / \mathrm{kg}$ bwt intravenously. Radiographs were taken using a $80 \mathrm{kV}, 15 \mathrm{~mA}, 1.99 \mathrm{sec}$ portable X-ray machine (Gierth HF 80/15 plus ULTRA LEICHT, Gierth X-Ray International $\mathrm{GmbH}$, Riesa, Germany). The focal-film distance (FFD) was $100 \mathrm{~cm}$, and regular speed screens were used.

The anatomical regions included in this study were: the phalanges for all horses 46 days to 24 months of age; and the carpus, elbow, hock, and stifle for all horses 8 months to 40 months of age. Two views, in the frontal (cranial to caudal) and sagittal (lateral to medial) plane, were taken for each region of the left thoracic and left pelvic limb. Sixteen different growth plates of the appendicular skeleton were examined. The radiographs were all interpreted by a panel consisting of at least three of the five authors and the classification of each physis was agreed upon by consensus.

For the purpose of this study, the growth plates were classified as fully open, closing and fully closed, in order of advancing fusion of the growth plate $[2,18,25,26]$. A growth plate was classified as fully open when a distinctly radiolucent line could be observed spanning the whole extent of the growth plate region (Fig. 1). A growth plate was classified as closing when a radiolucent line was present in the growth plate area, but only intermittently and surrounded by diffuse relatively increased bone opacity (Fig. 2). A growth plate was classified as fully closed with total absence of the radiolucent line in the region of the previous growth plate in the two radiographic projections (Fig. 3). When there was a difference in appearance of the growth plates on separate views of the same area, the growth plate was classified according to the view that showed the lowest degree of fusion. Other subjective features of the growth plates such as width were noted. Time of closure for each growth plate was defined as the age range from the youngest horse observed with a fully closed growth plate, to the age after which all further horses examined had a fully closed growth plate.
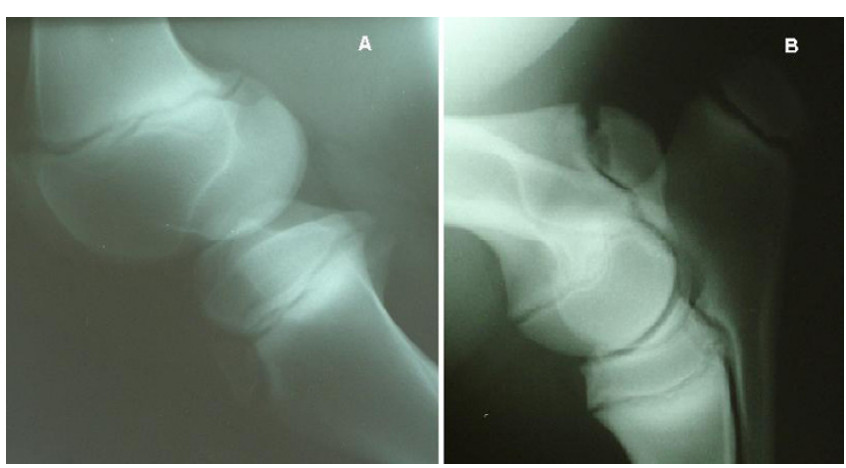

\section{Figure I}

Examples of fully open growth plates. A) The proximal tibia, tuberositas tibia and distal femur of a 46-day-old foal. B) The tuber olecrani, proximal radius and distal humerus of a 4-month-old foal

\section{Alkaline phosphatase and height at the withers}

Prior to sedation, blood was drawn from the external jugular vein into two $10 \mathrm{ml}$ vials without supplement. The whole blood was centrifuged later the same day and the serum frozen to $-18^{\circ} \mathrm{C}$ for later analysis or was analyzed directly. Total serum alkaline phosphatase (U/L) was measured with the Modified IFCC method [27]. The height at the highest point of the withers was measured with the horse standing square on a level surface. Most of the horses were measured under mild sedation because they were not used to extensive handling. In order to have reference values of total ALP of adult Icelandic horses, intravenous blood samples were collected from a control group which consisted of 11 reportedly healthy Icelandic horses at the age of 7 to 16 years.

\section{Results \\ Radiographic examination}

The growth plates in the first and second distal phalanges and the proximal third phalanx as well as the proximal Mt3 and Mc3 were all fully closed in the youngest horses in this study. The time of closure of the sixteen other growth plates examined are listed in Table 1, and in Table 2 these same results are listed together with published data from other horse breeds. The growth plates of the Icelandic horses were subjectively characterized as narrow in most of the regions studied, relative to those present in large horse breeds, although the width was not objectively measured.

\section{Alkaline phosphatase and height at the withers}

The results of the measurements of total ALP as well as the height at the withers are plotted against the age of the horses in Figures 4 and 5 respectively. A geometric trend line was added to the graphs in both figures. For comparison, the mean value of $242.5 \mathrm{U} / \mathrm{L}$ of total ALP of the con- 


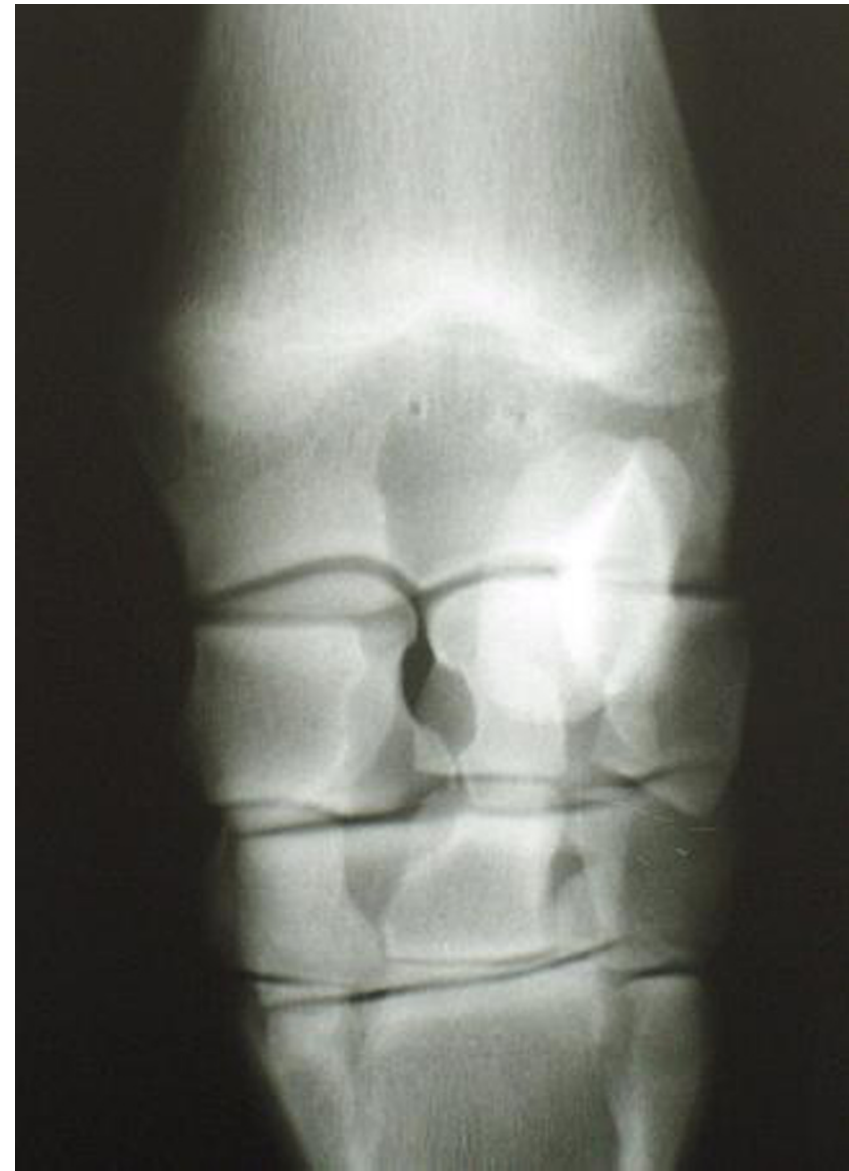

Figure 2

Example of a growth plate classified as closing. The carpus of a horse aged 26.7 months. The growth plate at the distal radius is classified as closing. Note the intermittently present radiolucent line surrounded by diffuse opacity (arrow).

trol group of 11 adult horses was added to Figure 4 as a dotted horizontal line.

No signs of osteochondrosis or other developmental orthopaedic disease was found in the neighbouring joints of the evaluated growth plates.

\section{Discussion}

A complete overview of the closure times of the appendicular growth plates requires either following a group of growing horses for several years, or studying a representative cross section of individuals at critical points of the development. Here, a cross-sectional design was chosen, as groups of individuals of the appropriate age could be captured on a few occasions during a calendar year. The material was haphazardly selected from farms in different locations in Iceland and Norway and is considered to be representative for the breed without known biases.
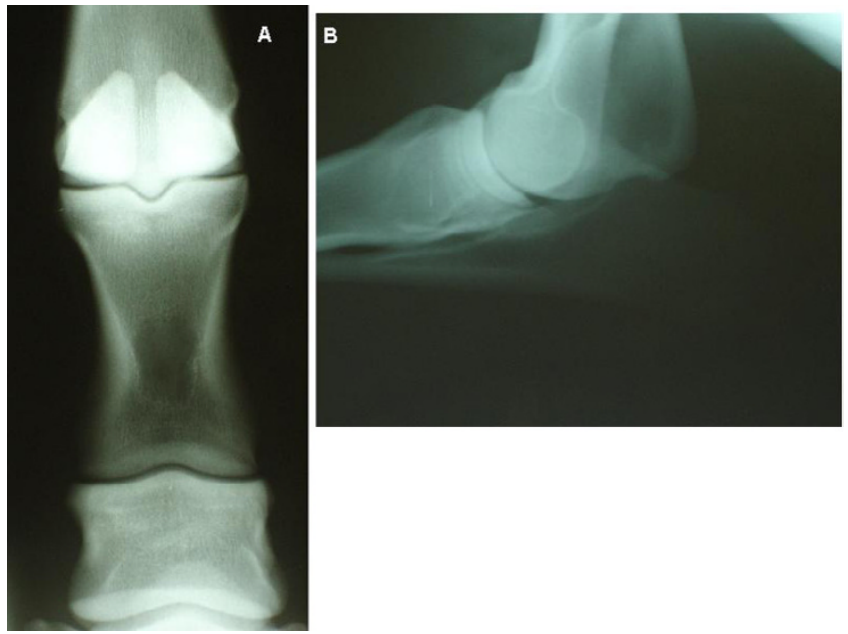

\section{Figure 3}

Examples of fully closed growth plates. A) Horse aged 22.8 months. Fully closed growth plates at the proximal second phalanx, proximal first phalanx and distal metacarpus. B) Horse aged 50.8 months. Fully closed growth plates at the proximal radius and distal humerus. Note the absence of any radiolucency and diffuse opacity in the region of the previous growth plate.

The closure times of the appendicular growth plates in the Icelandic horse listed in Table 1 were found to be similar to existing data for other horse breeds (see Table 2). The only exception was a tendency for the growth plates of the distal radius to close later in Icelandic horses, compared with Thoroughbred/Quarter horse crosses [14], Brazilian Thoroughbreds [26], Brazilian Mangalarga [18] and a limited material of Arabian horses [17]. However, few complete studies are presently available for comparison of our results. Many of the studies listed in Table 2 are based on a very limited number of young horses, and/or a limited number of growth plate regions. No previously published data could be found for many of the regions now investigated in the Icelandic horse. In general, the differences in the closure times of the growth plates appear to be minimal between breeds despite of the great variation in adult sizes. This suggests a slower growth rate in smaller breeds, such as the Icelandic horse. The consistent "subjective" observation of relatively narrow growth plates in this study, compared to the much wider growth plates observed in adolescent horses of large breeds, also supports this suggestion. Measuring the actual growth rate of the Icelandic horse would, however, have required measurements of the size at birth and was beyond the scope of this study.

The radiographic determination of growth plate closure is a result of subjective evaluation, and correct interpretation depends on many factors. To reveal the radiolucent carti- 
Table I: Radiographic closure time (age range in months) of appendicular growth plates in 64 Icelandic horses

\begin{tabular}{lccc}
\hline Growth plate & $\mathbf{n}$ & Growth plate fully open & Growth plate fully closed = Closure time \\
\hline Proximal second phalanx $(\mathrm{TL})$ & 35 & $1.5-6.1$ & 8.1 \\
Proximal first phalanx $(\mathrm{TL})$ & 37 & $1.5-4.3$ & $8.1-8.5$ \\
Proximal second phalanx $(\mathrm{PL})$ & 35 & $1.5-4.3$ & 8.1 \\
Proximal first phalanx $(\mathrm{PL})$ & 37 & $1.5-6.1$ & $8.1-8.5$ \\
Distal third metacarpal & 37 & $1.5-4.3$ & $8.1-14.9(16.4)$ \\
Distal third metatarsal & 37 & $1.5-6.1$ & $27.4-32.0(39.1)$ \\
Distal radius & 55 & $1.5-22.9$ & 14.9 \\
Proximal radius & 56 & $1.5-11.0$ & $31.5-32.2$ \\
Tuber olecrani & 55 & $1.5-26.7$ & 15.2 \\
Medial epicondyle of humerus & 56 & $1.5-14.9$ & $8.8-11.0$ \\
Distal humerus & 56 & $1.5-4.3$ & $19.0-26.7$ \\
Tuber calcanei & 56 & $1.5-11.0$ & $15.3-19.0$ \\
Distal tibia & 56 & $1.5-11.0$ & $38.6-40.1$ \\
Tuberositas tibiae & 52 & $1.5-38.6$ & $23.0-32.2(38.6)$ \\
Proximal tibia & 56 & $1.5-22.8$ & $19.0-27.0$ \\
Distal femur & 53 & $1.5-16.4$ & \\
\hline
\end{tabular}

Fully open = distinct radiolucent line spanning the entire extent of the physis; fully closed $=$ no radiolucency in the region of the physis. The Radiographic closure time was defined as the age range from the youngest horse observed with a fully closed physis, to the age after which all further horses had a fully closed physis. Single outliers which were in the "closing stage" are in parenthesis.

lage at the growth plate, the x-ray beam must be aimed directly perpendicularly to the growth plate; otherwise overlapping bone tissue can be misinterpreted as evidence of fusion of the growth plate. Since the growth plates in many sites are not flat discs, but undulate to a variable degree, often in two or more directions, the problem of overlapping is often present also in good-quality radiographs [28]. In addition, the physeal cartilage becomes narrower with increasing age [29], which makes it more difficult to discern between fully open and partially fused growth plates. Therefore, to minimize interpretation difficulties, two views (cranio - caudal and lateral - medial) of each region were used. In some cases, it was still difficult to distinguish between "late" closing and fully closed. This is a possible explanation to the outliers in the present study. Other authors have also found what seem to be single outliers in their material $[14,25]$.

Total serum alkaline phosphatase (total ALP) consists of fractions of several tissue-specific isoenzymes. In healthy

Table 2: Previously published reports of closure times (months) of the appendicular growth plates in different horse breeds together with the results for Icelandic horses in this study.

\begin{tabular}{|c|c|c|c|c|c|c|c|c|c|c|}
\hline \multirow[b]{2}{*}{ Breed } & \multirow[b]{2}{*}{$\mathbf{n}$} & \multicolumn{9}{|c|}{ Growth plate } \\
\hline & & $\begin{array}{l}\text { Proximal } \\
\text { second } \\
\text { phalanx }\end{array}$ & $\begin{array}{l}\text { Proximal } \\
\text { first phalanx }\end{array}$ & $\begin{array}{l}\text { Distal third } \\
\text { metacarpal }\end{array}$ & $\begin{array}{c}\text { Distal } \\
\text { third } \\
\text { metatarsal }\end{array}$ & $\begin{array}{l}\text { Distal } \\
\text { radius }\end{array}$ & $\begin{array}{l}\text { Proximal } \\
\text { radius }\end{array}$ & $\begin{array}{l}\text { Tuber } \\
\text { olecrani }\end{array}$ & $\begin{array}{c}\text { Distal } \\
\text { humerus }\end{array}$ & $\begin{array}{l}\text { Tuber } \\
\text { calcanei }\end{array}$ \\
\hline Brazilian Thorougbred [27] & 20 & & & & & $20.9-27.6$ & & & & \\
\hline Thoroughbred [19] & 800 & & $8.0-14.0$ & $8.0-14.0$ & & & & & & \\
\hline Thoroughbred [20] & 53 & & & & & & & & & $16.0-24.0$ \\
\hline American Standardbred [16] & 113 & & & & & $26.0-35.0$ & & & & \\
\hline Standardbred [13] & 14 & & & & & $24.2-31.9$ & & & & \\
\hline $\begin{array}{l}\text { American and Italian } \\
\text { Standardbred [15] }\end{array}$ & 140 & & & & & $26.0-29.0$ & & & & $23.0-27.0$ \\
\hline Arabian [14] & 2 & $7.5-7.9$ & $7.5-8.8$ & $7.0-7.5$ & $7.0-7.5$ & $23.2-23.7$ & $13.6-14.0$ & $26.6-29.7$ & $13.6-14.9$ & \\
\hline Quarter Horse [12] & 6 & & & & & & Ca. 18 & & & \\
\hline $\begin{array}{l}\text { Thoroughbred-Quarter Horse } \\
\text { Cross [II] }\end{array}$ & 9 & & $\begin{array}{l}6.0-10.0(\mathrm{tl})^{*} \\
8.0-11.0(\mathrm{pl})^{*}\end{array}$ & $\begin{array}{l}7.0-9.5 \\
(18)^{* * *}\end{array}$ & $9.0-12.5$ & $24.0-25.5$ & & & & \\
\hline Brazilian Manga-larga [17] & 7 & & & & & 24.6 & & & & \\
\hline Finnhorse [18] & 15 & & & & & $24.0-30.0$ & & & & \\
\hline Icelandic horse, current study & $35-56 * *$ & 8.1 & $8.1-8.5$ & $\begin{array}{l}8.1-8.5 \\
(16.4)^{* * * *}\end{array}$ & $\begin{array}{l}8.1-14.9 \\
(16.4)^{* * * *}\end{array}$ & $\begin{array}{l}27.4-32.0 \\
(39.1)^{* * * *}\end{array}$ & 14.9 & $31.5-32.2$ & $8.8-11.0$ & $19.0-26.7$ \\
\hline
\end{tabular}

$* \mathrm{tl}=$ thoracic limb, $\mathrm{pl}=$ pelvic limb, ${ }^{*}$ Depending on region, ${ }^{* * *}$ The closure times with single outliers are included in parentheses 


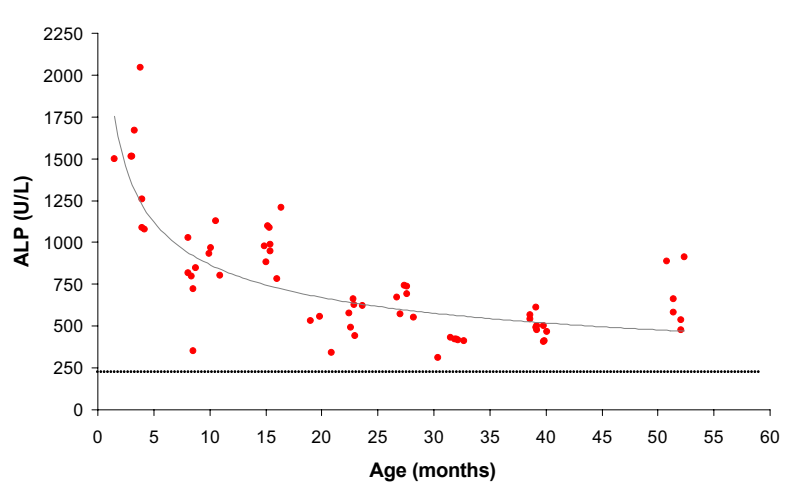

\section{Figure 4}

The relationship between alkaline phosphatase (ALP, in U/L) and age (in months) of 64 Icelandic horses with a fitted geometric curve. The dotted line at the ALP-level of $242.5 \mathrm{U} / \mathrm{L}$ represents the mean ALP value of the control group of II horses, which were 7 to 16 years of age.

young horses only two different isoenzyme fractions appear in the serum: liver and bone ALP [21]. The level of total ALP decreases with age, particularly during the first year of life, mainly due to the decrease of the bone fraction as the skeleton growth rate slows down with age $[22,23]$. In horses younger than one year, the bone fraction is $60 \%$ of the total ALP, while in horses over five years of age it has decreased to $20 \%$ [22]. The same pattern in the changes of total ALP with age was observed in the Icelandic horse (see Fig 4). The plots followed a fitted geometric curve that was steepest in the first year of life, and had almost reached a horizontal line at 38 to 40 months. At this age the growth plates studied were all closed and the height at the withers seemed to have reached the adult level. However, the total ALP in the three- and four-year-

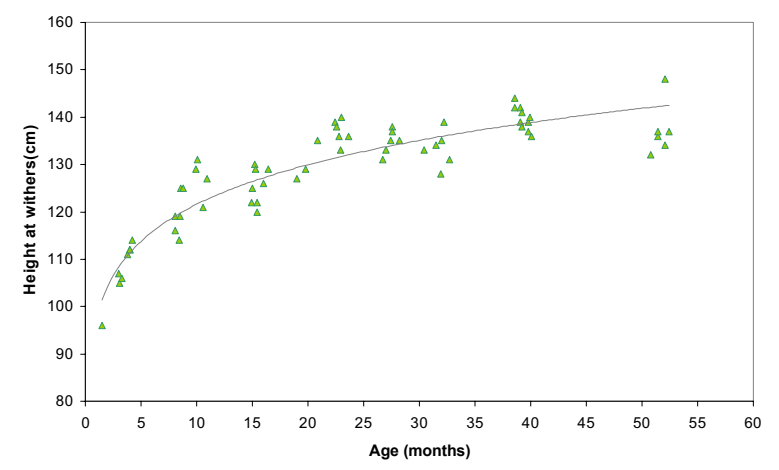

\section{Figure 5}

The relationship between height at the withers and age of 63 Icelandic horses. The fitted curve is a geometric model. old horses had still not decreased to the baseline value of the control group of 11 adult horses, and was also higher than in adult Icelandic horses in a previous study [30]. The mean total ALP in the four-year-old horses was 675.7 $\mathrm{U} / \mathrm{L}$, which was actually higher than in the three-year-olds that had a mean ALP of 497.4 U/L. Although all the growth plates in the current study were closed at the age of four years, it has been described that more proximal growth plates, for example in the pelvis and the vertebral column, can still be open at this age [31]. It is also known that considerable remodeling occurs at the physeal sites for a long time after radiological closure [16]. The fouryear-old horses were in light training which has been reported to cause an increase in both liver and bone ALP in Swedish Standardbred trotters up to the age of three years [21].

Radiographic signs of developmental orthopaedic disease were not identified in this material nor in an earlier report based on radiographic examination of the tarsi of 614 Icelandic horses in the age of $6-12$ years [32]. Thus no radiographic survey of Icelandic horses to date has demonstrated the existence of osteochondrosis type fragments.

\section{Conclusion}

This study provides practical information for trainers and veterinarians working with the Icelandic horse. Traditionally, demanding ridden training of Icelandic horses commences at the age of 4 years at the earliest. According to the current study, the appendicular skeleton should be ready for increased load at 3 years of age, as most appendicular growth plates are closed by then. The results also suggest that the Icelandic horse, with its gene pool established over 1000 years ago, has approximately the same growth period as breeds of horses which have been especially selected for size during the past few centuries. In our study the Icelandic horse was also subjectively evaluated to have relatively narrow growth plates, relative to large horse breeds, in all age groups suggesting a slower growth rate. The growth rate of the Icelandic horse needs to be investigated further, as well as the association between growth rate and developmental orthopaedic abnormalities.

\section{Competing interests}

The author(s) declare that they have no competing interests.

\section{Authors' contributions}

The authors contributed equally to this work. All authors read and approved the final manuscript. 


\section{Acknowledgements}

This study was supported by funds from Torsted's Trust Fund for Animal Welfare and the Norwegian School of Veterinary Science. The authors acknowledge the breeders providing horses and facilities for the study.

\section{References}

I. Pezzoli G, Del Bue M: Valutazione radiografica del grado di sviluppo scheletrico nel cavallo trottatore in rapporto all'attivita' atletica. (Evaluation of bone development in trotting horses and athletic activity). Folia Vet Lat I975, 5:399-4I I.

2. Gabel AA, Spencer CP, Pipers FS: A study of correlation of closure of the distal radial physis with performance and injury in the Standardbred. J Am Vet Med Assoc 1977, 170: I88-194.

3. Yoshida K, Ueda $\mathrm{Y}$, Masumitsu $\mathrm{H}$ : Radiological studies on the ossification of the Thoroughbreds 2. Closure process in the distal epiphyseal lines of the radius and the 3rd metacarpal bone and the proximal epiphyseal line of the proximal phalanx and an assessment system of bone maturity. Bull Equine Res Inst 1982, 19:18-29.

4. Ađalssteinsson $\mathrm{S}$ : Origin and conservation of farm animal populations in Iceland. Z Tierzuecht Zuechtsbiol 1981, 98:258-264.

5. Pálsson PA: Er íslenski hesturinn hreinræktaður í 1000 ár? (Is the Icelandic horse pure bred for a thousand years?). Eiðfaxi 1996, 2:18-19.

6. International Federation of Icelandic Horse Associations: Breeding [http://www.feif.org/breeding]

7. Árnason Th: Genetic studies on conformation and performance of Icelandic toelter horses. Acta Agric Scand 1984, 34:409-462.

8. Hugason K: Breeding of Icelandic toelter horses: an overview. Livest Prod Sci 1994, 40:2I-29.

9. Árnason Th, van Vleck LD: Genetic Improvement of the horse. In Genetics of the horse Edited by: Bowling AT, Ruvinsky A. New York: GABI Publishing; 2000:473-497.

10. Björnsdóttir S, Árnason Th, Lord P: Culling rate of Icelandic horses due to bone spavin. Acta Vet Scand 2003, 44:16I-169.

II. International Federation of Icelandic Horse Associations: National Breeding Statistics [http://www.feif.org/pdf/
a brnews I03e.pdf]

12. Árnason Th, Bjarnason Th: Growth and size of Icelandic toelter horses. Livest Prod Sci 1994, 40:79.

13. Sigurđsson Á, Fróđadóttir H, Jóhannsdóttir LB: Skýrsluhaldið í hrossarækt 200I. (Annual report on horse breeding 200I). Freyr 2002, I:47-50.

14. Fretz PB, Cymbaluk NF, Pharr JW: Quantitative analysis of longbone growth in the horse. Am J Vet Res 1984, 45:1602-1609.

15. Smith BL, Auer JA, Taylor TS, Hulse DS, Longnecker MT: Use of orthopedic markers for quantitative determination of proximal radial and ulnar growth in foals. Am J Vet Res |99|, 52: |456-| 460 .

16. Uhlhorn H, Eksell P, Carlsten J: Scintigraphic characterization of distal radial physeal closure in young standardbred racehorses. Vet Radiol Ultrasound 2000, 41:8I-186.

17. Myers VS, Emmerson MA: The age and manner of epiphyseal closure in the forelegs of two Arabian foals. Vet Radiol Ultrasound 1966, 7:39-47.

18. Mamprim MJ, Vulcano LC, Muniz LMR: Estudo radiográfico do fechamento da epífise distal da rádio em potras de raça Manga-Larga. (Radiographic study of distal radius epiphyseal closure in Manga-Larga fillies.). Vet E Zoot 1992, 4:59-62.

19. Koskinen E, Katila T: Effect of I9-Norandrostenololylaurate on serum testosterone concentration, libido, and closure of distal radial growth plate in colts. Acta Vet Scand 1997, 38:59-67.

20. Banks WC, Kemler AG, Guttridge H, Kirkham W: Radiography of the Tuber calcis and its use in Thoroughbred training. Proc Am Ass Equine Practnrs 1969, 15:273-293.

21. Thorén-Tolling K: Serum Alkaline Phosphatase isonezymes in the horse - variation with age, training and in different pathological conditions. J Vet Med A 1988, 35: 13-23.

22. Price JS, Jackson B, Eastell R, Goodship AE, Blumsohn A, Wright I, Stoneham S, Lanyon LE, Russell RGG: Age related changes in biochemical markers of bone metabolism in horses. Equine Vet J 1995, 27:201-207.

23. Price JS, Jackson BF, Gray JA, Harris PA, Wright IM, Pfeiffer DU, Robins SP, Eastell R, Ricketts SW: Biochemical markers of bone metabolism in growing thoroughbreds: a longitudinal study. Res Vet Sci 200I, 71:37-44.

24. Mäenpää PH, Pirskanen A, Koskinen E: Biochemical indicators of bone formation in foals after transfer from pasture to stables for the winter months. Am J Vet Res 1988, 49:1990-1992.

25. Mason TA, Bourke JM: Closure of the distal radial epiphysis and its relationship to unsoundness in two year old thoroughbreds. Aust Vet J 1973, 49:221-228.

26. Vulcano LC, Mamprim MJ, Muniz LMR, Moreira AF, Luna SPL: Radiographic study of distal radial physeal closure in Thoroughbred horses. Vet Radiol Ultrasound 1997, 38:352-354.

27. Tietz NW: Clinical Guide to Laboratory Tests Philadelphia, Pennsylvania: WB Saunders Company; 1995.

28. MacCallum FJ, Brown MP, Goyal HO: An assessment of ossification and radiological interpretation in limbs of growing horses. Br Vet J 1978, 134:366-374.

29. Firth EC, Greydanus Y: Cartilage thickness measurements in foals. Res Vet Sci 1987, 42:35-46.

30. Seiser M, Strasser A, Hofbauer B: Der Einfluss von Alter und Geschlecht auf diagnostisch wesentlichen Blutparameter bei Islandpferden. (The influence of age and gender on diagnostically significant blood parameters in Icelandic horses.). Tierarztl Prax 200I, 29(G):324-32I.

31. Butler JA, Colles CM, Dyson SJ, Kold SE, Poulos PW: Clinical Radiology of the Horse Oxford: Blackwell Science Ltd; 2000.

32. Björnsdóttir S, Axelsson M, Eksell P, Sigurdsson H, Carlsten J: Radiographic and clinical survey of degenerative joint disease in the distal tarsal joints in Icelandic horses. Equine Vet J 2000, 32:268-272

Publish with Bio Med Central and every scientist can read your work free of charge

"BioMed Central will be the most significant development for disseminating the results of biomedical research in our lifetime. "

Sir Paul Nurse, Cancer Research UK

Your research papers will be:

- available free of charge to the entire biomedical community

- peer reviewed and published immediately upon acceptance

- cited in PubMed and archived on PubMed Central

- yours - you keep the copyright

Submit your manuscript here:

http://www.biomedcentral.com/info/publishing_adv.asp
BioMedcentral 